\title{
Cardiac Arrest Developing Linked to Hydatid Cyst Rupture During Operation of a Pediatric Patient
}

\author{
Pediatrik Hastanın Operasyonu Esnasında Kist \\ Hidatik Rüptürüne Bağlı Gelişen Kardiyak Arrest
}

\begin{abstract}
Hydatid cysts are parasitic infections caused by echinococcus granulosus and echinococcus alveolaris. These infections are characterized by cystic formations most commonly localized in the liver and lungs. These cysts demonstrate widespread hepatic, and pulmonary involvement. Rupture of the cyst due to trauma, spontaneously or during surgical intervention may lead to anaphylactic shock or even death. During hydatid cyst operations, suddenly developing desaturation, tachycardia and hypotension should lead to the consideration of anaphylaxis. These complications should remind us that patients being operated for hydatid cysts may develop anaphylaxis and preparations should be made for this complication, and dialogue with the surgical team may reduce mortality and morbidity rates. In this case report we present a patient undergoing surgical excision of hepatic hydatid cyst who developed anaphylactic shock and resulting cardiac arrest due to rupture of the cyst and traumatization of the hepatic vein.
\end{abstract}

Keywords: Hepatic echinococcosis, cardiac arrest, anaphylaxis

Öz

Kist hidatik ekinokokkozis granülosuz ve ekinokokkozis alveolaris tarafindan oluşturulan parazitik bir enfeksiyondur. Bu enfeksiyonlar kistlere sahip kist karakterindedir ve yaygın olarak karaciğer ve akciğer tutulumu gösterirler. Kist travma, spontan ya da cerrahi müdahaleyle rüptüre olabilir, sonuç olarak anaflaktik şok hatta ölüm gelişebilir.Kist hidatik operasyonu sırasında anlık gelişen satürasyon düşüklüğü, hipotansiyon ve taşikardi anaflaksi gelişimiyle ilişkili olabilir. Bu bize cerrahi ekip ve hasta ile mortalite ve morbidite konusunda konuşmamız gerektiğini hatırlatmalıdır. Biz bu çalışmada karaciğer kist hidatiğinin cerrahi olarak çıkarılması esnasında hepatik ven travmatizasyonu ve kist rüptürü sonucu anaflaksi ve buna bağıı kardiyak arrest gelişen pediatrik hastayı sunmayı amaçladık.
Alındığı tarih: 04.04 .2018

Kabul tarihi: 18.07.2018 Online Yayın tarihi: 14.03.2019

Abdulkadir Yektaş TC. Sağlık Bilimleri Üniversitesi, Diyarbakır Gazi Yaşargil Eğitim ve Araştırma Hastanesi, İstanbul, Türkiye

akyektas722000@yahoo.co.uk ORCID: 0000-0003-4400-548X

B. Balkan 0000-0003-3510-6991

H. Çetingök 0000-0002-6746-9079

N. Saygı Emir 0000-0002-7244-5805

M. Köyyeri 0000-0003-0711-9778

M. Aslan 0000-0002-0499-6859

E. Güngördü 0000-0002-6050-9058 $S B U ̈$. Dr. Sadi Konuk EAH

Anesteziyoloji ve Reanimasyon Kliniği istanbul, Türkiye

Anahtar kelimeler: Hepatik ekinokokkozis, kardiyak arrest, anaflaksi

\section{INTRODUCTION}

Hydatid cyst disease is a parasitic disease caused by echinococcus granulosus and echinococcus alveolaris ${ }^{(1)}$. Embryos in the form of cysts are mainly placed in the liver. Additionally, together with the liver, it may spread to other organs, especially to the lungs and less frequently to the brain, kidneys, heart and bones ${ }^{(2)}$. A study investigating the incidence of anaphylaxis in England showed that patients with asthma had higher rates of anaphylaxis compared to those without asthma ${ }^{(3)}$. The anaphylactic reaction developing due the hydatid cyst contents entering into blood circulation is a serious but rare complication of surgery ${ }^{(4)}$. Anaphylaxis is a sudden, unwanted hypersensitive reaction that may cause severe clinical manifestations which may lead to death due to vascular collapse and airway obstruction ${ }^{(5)}$.

In this report we attempt to present our patient who underwent surgical procedure for removal of the cyst close to the hepatic vein in whom hemorrhage and cyst rupture occurred due to fibrous adhesion, and the cyst was rapidly absorbed by the damaged hepatic vein which led to severe bronchospasm and anaphylactic shock with secondary cardiac arrest. 


\section{CASE}

A 13-year old, $55 \mathrm{~kg}$-male patient scheduled for surgery with the indication of liver hydatid cyst had a history of asthma, finger amputation due to trauma one, appendectomy two years previously and his mother had restless leg syndrome. His physical examination findings were unremarkable. Laboratory values were within normal levels. Abdominal computed tomography of the patient found two mass lesions measuring $125 \times 96 \mathrm{~mm}$ and $65 \times 63 \mathrm{~mm}$ on the right lobe of the liver, completely covering the lobe compatible with hydatid cyst (Figure 1). Liver hydatid cyst was diagnosed and operation was planned.

The patient was assessed routinely by the anesthesia clinic before the operation and his ASA II status with no disease other than asthma was determined. Informed consent was obtained from the patient before the operation. Before the operation he was taken to the operating room and electrocardiography (ECG), noninvasive monitoring of blood

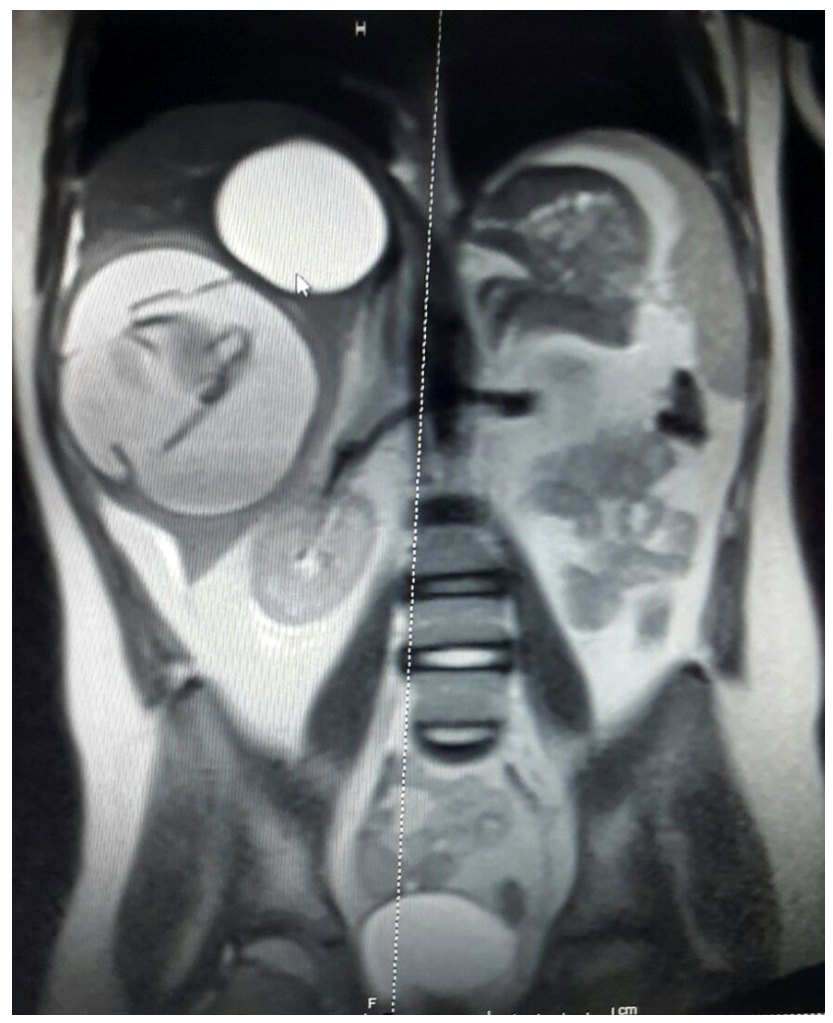

Figure 1. pressure and peripheral oxygen saturation was performed. Peripheral venous route was opened and infusion of balanced fluid was initiated. His systemic arterial pressure $(S A B)(100 / 52 \mathrm{mmHg})$, heart rate (HR) (100 bpm) and peripheral oxygen saturation $\left(\mathrm{SPO}_{2}\right)(99 \%)$ were as indicated. For induction of general anesthesia, $3 \mathrm{mg}$ midazolam (Dormicum, Roche), $2 \mathrm{mg} / \mathrm{kg}$ propofol (Propofol, Fresenius cabi, Sweden), $2 \mu \mathrm{g} / \mathrm{kg}$ fentanyl (Braun, Germany) and $0.6 \mathrm{mg} / \mathrm{kg}$ rocuronium were used. After orotracheal intubation with a $6 \mathrm{~mm}$ endotracheal tube, for anesthesia maintenance a combination of MAC 2 concentration of sevoflurane (Abbott, USA) and 50\% oxygen $+50 \%$ air with remifentanil infusion of $0.05 \mathrm{mcg} / \mathrm{kg} / \mathrm{hr}$ was administered. Using positive pressure ventilation for the lungs, ventilation continued in pressure-controlled mode with end-tidal $\mathrm{CO}_{2}$ pressure of 35 $\mathrm{mmHg}$. At the beginning of the operation, the case was hemodynamically stable. Ten minutes after anesthesia induction, the surgical team began the operation. The cyst measuring $125 \times 96 \mathrm{~mm}$ had cyst wall, germinal membrane and daughter cysts observed with the area where the cyst was removed and irrigated with $3 \% \mathrm{NaCl}$. The cyst was removed together with the wall and anesthesia continued without problems for 90 minutes. The second cyst measuring $65 \times 63 \mathrm{~mm}$ diameter had fibrous adhesions to the branches of hepatic vein. During removal of the cyst, hepatic vein bled. After the surgical team warned of hemorrhage, the patient's systemic arterial tension was $75 / 53 \mathrm{mmHg}$, heart rate 120 bpm and the patient was desaturation. Respiratory sounds could not be heard and the patient was considered to be desaturated secondary to asthma. Anesthesia was deepened, the tube was checked but desaturation did not resolve so the intubation tube was changed but still desaturation continued. While considering whether the cause of desaturation was hemorrhage, asthma or pulmonary embolism, peripheral oxygen saturation fell to $15 \%$ and heart rate to $55 \mathrm{bpm}$. The operation was stopped and resuscitation began to relieve the shock Controlled ventilation with $100 \%$ oxygen was ensured. Epinephrine $1 \mathrm{mg}$, feniramine maleate $45.5 \mathrm{mg}$ (Avil, Sandoz Turkey), methylprednisolone $100 \mathrm{mg}$ and 
ranitidine $50 \mathrm{mg}$ were administered intravenously. Four minutes later, epinephrine (1 mg IV) was administered again. Within 5 minutes the patient's heart rate was $170 \mathrm{bpm}$ with systemic arterial tension of $150 / 79 \mathrm{mmHg}$. In conversing with the surgical team it was learned that the cyst had ruptured during excision. The cyst fluid from the ruptured cyst entered systemic circulation through the damaged hepatic vein branches and was considered to induce anaphylactic shock and cardiac arrest. The patient's lungs were auscultated and lengthened expirium and wheezing in the lower zones were found. Another venous route was opened and rapid colloid and crystalloid infusion was administered. Later the patient's systemic arterial tension and peripheral oxygen saturation began to fall so adrenalin infusion $(0.02 \mathrm{mg} /$ $\mathrm{kg} / \mathrm{min}$ ) was begun. The surgical team cleaned the ruptured cyst and repaired the hepatic vein. The patient had arterial cannulation and monitoring was performed. Initial arterial blood gas values were $\mathrm{pH}$ : 7.23 (7.35-7.45), $\mathrm{PaCO}_{2}: 60$ (35-45) $\mathrm{mmHg} \mathrm{PaO}_{2}$ : $59.6(75-100) \mathrm{mmHg}$, lactate $1.4(0.5-2) \mathrm{mmol} / \mathrm{l}$ and $\mathrm{HCO}_{3}: 21.5(22-26) \mathrm{mmol} / \mathrm{l}$. After the surgical procedure finished and hemodynamic status was stabilized, the intubated child was sent to the intensive care unit.

When the patient was admitted to the intensive care unit mechanical ventilation was begun in the presence of the following parametres: peak heart rate, $120 \mathrm{bpm}, \mathrm{SPO}_{2}, 100 \%$, PRVC mode $\mathrm{FiO}_{2} 0.5$, frequency $15 / \mathrm{min}$, PEEP 8 , and tidal volume $300 \mathrm{ml}$. Temperature-sensitive urinary catether was inserted. Administration of body weight-adjusted doses of vancomycin, meropenem, metronidazole and albendazole was begun. After a loading dose of 200 cc maintenance treatment with $3 \% \mathrm{NaCl}$ infusion at a rate of $20 \mathrm{cc} / \mathrm{h}$ was begun. With capillary filling time of 3 seconds and good cardiac output, the patient's adrenalin infusion was stopped and noradrenalin infusion at a dose of $0.1 \mathrm{mcg} / \mathrm{kg} / \mathrm{min}$ was begun with addition of $2 \mathrm{mg}$ methylprednisolone, ranitidine and fluid infusion. When the patient's pressure was stable the noradrenalin infusion was discontinued. With blood gas and auscultatory sounds improved, the patient was monitored in BIPAP mode. After blood gas, other laboratory results and clinic were assessed in the stable patient, he was extubated. On the $2^{\text {nd }}$ day of admission the patient had Glasgow Coma Scale of 15 and treatment continued. With completion of treatment on the $6^{\text {th }}$ day, the patient was discharged from the intensive care unit.

\section{DISCUSSION}

Anaphylactic reactions occurring during surgery may cause many signs and symptoms. Redness, urticaria and edema are common, but these signs may be missed during surgery as the patient is covered. If the most commonly observed cardiovascular symptoms of hypotension and tachycardia are missed and treatment does not begin, rapidly severe arrhythmia and cardiovascular collapse may develop. Bronchospasm is less commonly observed, but may occur more frequently in asthmatic patients. The basic symptoms of patients under general anesthesia are hypotension, bronchospasm and urticaria ${ }^{(6)}$. A study performed in California reported that the incidence of anaphylaxis was five times higher in patients with asthma compared to those without asthma ${ }^{(7)}$.

In cases with liver hydatid cyst, it has been reported that the cyst contents mixing with systemic circulation during surgery or the solutions used to kill the scolex may cause anaphylactic reactions ${ }^{(8)}$. During general anesthesia many different pharmacological agents that may cause anaphylaxis or anaphylactoid reactions are used ${ }^{(9)}$.

In children the epinephrine dose is $0.01 \mathrm{mg} / \mathrm{kg}$ with a maximum dose of $0.3 \mathrm{mg}$. Due to the lethal arrhythmia risk of adrenalin infusion, it should be administered with hemodynamic monitoring ${ }^{(10)}$. For in-hospital cardiac arrest (IHCA) in children, resuscitation applications together with increasing the adrenalin dose at intervals have led to an increase in survival and hospital discharge rates. In this situation the increasing adrenalin dose interval is associated with increased survival and hospital discharge rates ${ }^{(11)}$.

In our case we did not consider the reaction was due to the solutions or anesthetic medications until 90 minutes had passed since the start of general 
anesthesia and the reaction developed 30 minutes after infusion of $3 \% \mathrm{NaCl}$ was used to kill the scolices in the the large cyst. Due to the dramatic progression of anaphylaxis, clinical diagnosis was not easily made. Our case had a history of asthma and very severe bronchospasm. Urticaria, angioedema and redness did not develop so other diagnoses were considered. With the fall in end-tidal carbon dioxide pulmonary embolism was considered with uncertain hypotension and initial sudden increase in heart rate linked to hemorrhage. The surgeons only stated that the patient wasbleeding. When the patient went into arrest, the surgical team stated the cyst had ruptured close to the damaged hepatic vein. We administered an unusually high dose of $0.2 \mathrm{mg} / \mathrm{kg}$ ephinephrine to the patient and received a response.

In conclusion, early diagnosis and treatment of anaphylaxis occurring during surgery is very important to reduce mortality and morbidity rates in patients. It should be remembered that patients operated for hydatid cyst may develop anaphylaxis and that very severe bronchospasm may cause anaphylactic shock. We believe that being prepared for this situation will dramatically reduce mortality and morbidity rates.

\section{REFERENCES}

1. Esme $\mathrm{H}$, Şahin DA. Tretment of Poumonary Hydatıd Cyst: Review. Türkiye Klinikleri J Med Sci. 2007;27(6):870-5.
2. Çelik M, Şenol C, Keles M, et al. surgical treatment of pulmonary hydatid disease in children: report of 122 cases. J Pediatr Surg. 2000;35:1710-3.

3. González-Pérez A, Aponte Z, Vidaurre CF, Rodríguez LA. Anaphylaxis epidemiology in patients with and patients without asthma: a United Kingdom database review. J Allergy Clin Immunol. 2010;125:1098-104. https://doi.org/10.1016/j.jaci.2010.02.009

4. Li Y, Zheng H, Cao X, Liu Z, Chen L. Demographic and clinical characteristics of patients with anaphylactic shock after surgery for cystic echinococcosis. Am J Trop Med Hyg. 2011;85:452-5.

https://doi.org/10.4269/ajtmh.2011.10-0448

5. Karaman Ö, Köse S. Anafilaksi. Klinik Pediatri, 2003;2(3);8997.

6. Inal MT, Memiş D, Akın F, Sezer A. Allergic reaction during hydatid cyst operation: Case report. Trakya Univ Tip Fak Derg. 2008;25(3):238-40.

7. Iribarren C, Tolstykh IV, Miller MK, Eisner MD. Asthma and the prospective risk of anaphylactic shock and other allergy diagnoses in a large integrated healthcare delivery system. Ann Allergy Asthma Immunol. 2010;104:371-7. https://doi.org/10.1016/j.anai.2010.03.004

8. Taşpınar V, Erdem D, Erk G, Baydar M, Göğüş N. Intraoperative anaphylaxis caused by a hydatid cyst. Case report. Turkiye Klinikleri J Anest Reanim. 2004;2(1):36-40.

9. Li Y, Zheng H, Cao X, Liu Z, Chen L. Demographic and clinical characteristics of patients with anaphylactic shock after surgery for cystic echinococcosis. Am J Trop Med Hyg. 2011;85:452-5. https://doi.org/10.4269/ajtmh.2011.10-0448

10. Lieberman P, Nicklas RA, Oppenheimer J, Kemp SF, Lang DM, Bernstein DI, et al. The diagnosis and management of anaphylaxis practice parameter: 2010 update. J Allergy Clin Immunol. 2010;126(3):477-80.

https://doi.org/10.1016/j.jaci.2010.06.022

11. Hoyme DB, Patel SS, Samson RA, Raymond TT, Nadkarni VM, Gaies MG. American Heart Association Get With the Guidelines-Resuscitation Investigators. (2017). Epinephrine Dosing Interval and Survival Outcomes During Pediatric In-Hospital Cardiac Arrest. Resuscitation.

https://doi.org/10.1016/j.resuscitation.2017.05.023 